\title{
Social representations of violence against rural women: unveiling senses in multiple views*
}

\author{
REPRESENTAÇÕES SOCIAIS DA VIOLÊNCIA CONTRA MULHERES RURAIS: \\ DESVELANDO SENTIDOS EM MÚLTIPLOS OLHARES
}

\section{REPRESENTACIONES SOCIALES DE LA VIOLENCIA CONTRA MUJERES RURALES: DESVELANDO SENTIDOS EN MÚLTIPLES MIRADAS}

\section{Marta Cocco da Costa', Marta Julia Marques Lopes², Joannie dos Santos Fachinelli Soares ${ }^{3}$}

\begin{abstract}
We analyze the social representations of violence against women from the perspective of city managers, professionals and health workers in rural settings of the southern half of Rio Grande do Sul. The study has a qualitative approach and adds a theoretical/methodological perspective of social representations. The data were generated by means of the associative method, question-stimulus of words and expressions emergence. The analysis of word association was performed with EVOC software, considering frequency and order of association with inducing terms. Participants recognize violence against women as gender destination that induces consent, resignation, guilt and fear, and results in naturalization and trivialization of this social phenomenon. We highlight the need to produce ruptures in established and traditional forms of health care, in the conservative and stereotypical views of violence, favoring access to friendly service and avoiding the reproduction of gender inequalities.
\end{abstract}

\section{RESUMO}

Analisam-se as representações sociais da violência contra as mulheres na perspectiva de gestores municipais, profissionais e trabalhadores da saúde em cenários rurais da metade sul do Rio Grande do Sul. O estudo tem abordagem qualitativa e agrega a perspectiva teórico-metodológica das Representações Sociais. Os dados foram gerados por meio do método associativo, com questão-estímulo de evocações de palavras e expressões. A análise da associação de palavras foi realizada com o auxílio do software EVOC, considerando a frequência e a ordem da associação aos termos indutores. Os participantes reconhecem a violência contra as mulheres como destino de gênero que induz a consentimento, resignação, culpa e medo, e resulta em naturalização e banalização do fenômeno social. Ressalta-se a necessidade de produzir rupturas nas formas instituídas e tradicionais de cuidado em saúde, nas visões conservadoras e estereotipadas da violência, favorecendo o acesso a serviços acolhedores e evitando a reprodução de iniquidades de gênero.

\author{
DESCRITORES \\ Atenção Primária à Saúde \\ Violência contra a mulher \\ População rural \\ Pessoal de saúde \\ Gestor de saúde \\ Relações profissional-paciente
}

\section{RESUMEN}

Se analizan las representaciones sociales de la violencia contra las mujeres desde la perspectiva de gestores municipales, profesionales y trabajadores de salud en el escenario rural de la mitad sur del Rio Grande do Sul. Este estudio con abordaje cualitativo incluye la perspectiva teórico-metodológica de las Representaciones Sociales. Los datos fueron generados por medio del método asociativo con preguntas-estímulo de evocaciones de palabras y expresiones. El análisis de la asociación de palabras fue realizada por medio del programa EVOC, considerando la frecuencia y el orden de la asociación a los términos inductores. Las evocaciones de los participantes reconocen la violencia contra las mujeres como destino de género que inducen a consentimiento, resignación, culpa y miedo resultando en naturalización y banalización del fenómeno social. Destaca la necesidad de producir rupturas en las formas tradicionales del cuidado de la salud, en las visiones conservadoras y estereotipadas de la comprensión de la violencia, favoreciendo el acceso a servicios de acogida y evitando la reproducción de inequidades de género.

\author{
DESCRIPTORES \\ Atención Primaria de Salud \\ Violencia contra la mujer \\ Población rural \\ Personal de salud \\ Gestor de salud \\ Relaciones profesional-paciente
}

"Extracted from thesis "Violence against rural women, city public agendas and professional health practices: the visible and the invisible in the obvious unconsciousness", Federal University of Rio Grande do Sul, 2012. ${ }^{1}$ Associate Professor, Federal University of Santa Maria, Campus Palmeira das Missões, RS, Brazil. marta.c.c@ufsm.br ${ }^{2}$ Tenure professor, Federal University of Rio Grande do Sul, Porto Alegre, RS, Brazil. ${ }^{3}$ PhD candidate in Nursing, Federal University of Rio Grande do Sul, Porto Alegre, RS, Brazil. 


\section{INTRODUCTION}

Violence against women is present in every society, a phenomenon related to the construction of gender and the distribution of power within each social group. It is pointed out that relations between men and women are under conflict and the interactive forms, in crisis, that is, under threat of collapse of traditional domination. Thus, violence can be understood as power reconquering behavior or to prevent its loss ${ }^{(1)}$.

In rural areas, violence acquires complex and multiple forms and manifests itself in everyday social relations, evidenced by discrimination as to ownership, the tract and land management, overload of work justified by asymmetries of power that underlie intra-familiar and social hierarchies, and in the masculine legitimacy of the gender division of labor within the family farming scenario.

In health area, for a long historical period, the naturalization of gender violence consolidated decisions of omission or claimed the lack of views that allowed public recognition (and diagnosis) of violent events and its constitution as a problem of public health, which could be prevented or intervened, beyond the limits of police coercion and reduce it to a matter of public safety.

In many cases, interventions in situations of violence against women occur only when the consequences are perceived as a disease, otherwise the complaint is not considered in health actions and consequences are referred to social and/or psychological order. Thus, health professionals' conduct is not caring to women's needs, restricting their actions to referrals, resulting in inadequate responses to the their demands ${ }^{(2-3)}$.

Then, we observed a tendency towards biologicist reductionism in a fragmented attention to women's health. Health professionals appear to be untrained to act in these situations, which can be explained by insufficient academic training in health area in relation to violence and lack of institutional support and multidisciplinary team to assist in this demand ${ }^{(4)}$.

It is believed that understanding such omission of decisions, in the field of violence, requires plural elements of analytical reading and, in this sense, approaches are proposed to the theory of Social Representations. The theory of Social Representations (SR) denotes a set of phenomena, concepts that comprise the theory constructed to explain them. The SR are interpretive forms of social reality and are primarily intended to make something unfamiliar in familiar, or unfamiliarity itself and, therefore, uses two interpretative mechanisms: anchoring and objectification that act having memory as its base. These mechanisms can apprehend the way in which the social transform a knowledge into representation and how this representation transforms the social, and understand the relationship between cognitive activity and social conditions in which the representations are built ${ }^{(4)}$.
Following these ideas, the notion of SR may help in the rescue of four important dimensions in studies that seek to understand individuals and groups: cognitive, affective, symbolic and imaginary; the role of the subject as a producer of symbolic and social systems; the emphasis in the study of complex symbolic systems; intra and inter-group interactions; functioning and the change of a society ${ }^{(5)}$.

When we choose to analyze the phenomenon of violence against rural women, from the perspective of gender and Social Representations, we sought to dismiss abstract definitions, directing the study to the relativity of these notions, of the multiplicity of behaviors guiding values and inter-influences in the social field in which they are built. In this approach, we understand that social actors nominate as violence, it varies according to the representations that make the phenomenon and according to the nature of the society where the phenomenon is defined ${ }^{(6)}$.

This study aims to know and analyze descriptively, in rural settings of the southern half of Rio Grande do Sul, the social representations of violence against women from the perspective of city managers, professionals and health professionals.

\section{METHOD}

In order to achieve the proposed objective, we chose to develop a qualitative study, adding the domain and theoretical-methodological perspective of Social Representations (SR). The research, in this perspective, committed to natural and complex social situations, is necessarily a qualitative research, a specific tradition within the social sciences that fundamentally depends on the observation of people in their own territory and interacting with these people through their own language ${ }^{(7)}$.

It was elected as a space for interaction and cultural land, the geographical base of the Interdisciplinary Research Program (PROINTER). The area chosen for the development of this program was the southern half of the State of Rio Grande do Sul, which has been increasingly suffering from economic downturn compared to other regions of the state, which makes regional disparities visible. However, due to the size of the area, the need to reduce it to eight iconic cities of the characteristics of this region emerged, which are: Arambaré, Camaquã Canguçu, Chuvisca, Crystal, Encruzilhada do Sul, Santana da Boa Vista and São Lourenço do Sul.

The research participants were 56 subjects, consisting of specialties' groups of professionals and/or active in public management, city managers, professionals responsible for women's health and health professionals, who work in rural areas and who were working at the moment of data-generation.
Social representations of violence against rural women: unveiling senses in multiple views Costa MC, Lopes MJM, Soares JSF 
For the data production/generation, an instrument that allowed to apprehend representations was used, being adapted and coming from the associative method, which sought to focus the less controlled, more spontaneous and more authentic verbal expression ${ }^{(8)}$. We opted to use the free association of words, considering the broad dimension of the term or inducing words violence against rural women. Data-generation occurred between September and November 2010.

Free association is a major technique for the recognition of the constituent elements of a representation content, the central core of understanding, in order to reduce the difficulty or the limits of discursive expression. With this technique, the interviewed participant is asked to say all the words, terms or expressions that come to mind from the inducers words and terms. The spontaneous character and projective dimension of this technique allowed access to the semantic universe (meaning) of the studied object ${ }^{(8)}$.

The technique of free association was treated in two stages: first, to recognize and analyze the categorical system or the logic used by interviewees, allowing the surrounding of the actual content of the representation. The second moment highlighted the organizers elements of content, from the frequency of the item in the population, their order of appearance in the association and the importance of the item to the subjects. In data-generation for the free association of words, we opted for the natural order of emergences.

Emergences were previously organized, constituting a corpus for analysis. The material was analyzed by the Ensemble des programmes permettant l'analyse des évocations (EVOC), which calculates, for the whole corpus, the simple frequency of each word emerged, mean orders of emergence of each word and average of emergence orders. This software has enabled subprograms that allowed us statistical data generation. This resource helped organize and allowed the quantification of the emerged words, the intersection between the frequency of each one and the emergence order, allowing two types of analysis: lexicography and categorization for content analysis ${ }^{(9)}$.

From the distribution of data in the four quadrant houses, we obtained the words that composes the semantic universe of the central and peripheral system. In the upper left quadrant, there are the truly significant terms for the subjects and that constitute them, probably, the central core of the studied representation. Words located in the right upper quadrant, are called first periphery; at lower left are located the contrasting elements; and those located in the lower right quadrant are the second periphery of representation ${ }^{(9-10)}$.

An analysis was also developed from the subprogram COMPLEX of EVOC 2000, which allowed us a statistical description of words, which helped us to understand that
Social Representation is more characteristic of a subset than the other and the common elements between the subgroups. To differentiate these subgroups, we used the variable characteristics of participants.

The COMPLEX generated a list that includes the comparison between the terms obtained by two subgroups, with the words spoken by only one group and also words common to both groups, with statistical calculations highlighting of which subgroup the term is characteristic, and the program considers the most common from the frequency greater than 5 .

Considering the Moscovicians' arguments $^{(5)}$, the analyzes were prepared in the instrumental categories defined by the occupational origin of the participants: managers, nurses, physicians and community health agents, and for the theoretical categories based on the concepts of objectification and anchoring (fundamental processes in creating the SR). The objectification transforms something strange into something almost concrete, transform what is in the mind of something that exists in the physical world. Anchoring tries to anchor strange ideas, reduced to common images and categories, putting them in a family context.

From the point of view of methodological techniques, the organization of SR, from a central core and a peripheral system, constitutes a contribution to the practical efficiency of the analysis among the material and the symbolic. Therefore, allied instrumental categories, theoretical, and methodological techniques.

This study was conducted in a way so that the rules of Resolution 196, of October 10, 1996 were respected, with a commitment to provide maximum benefits and minimal risks and harm to the subjects involved. We obtained approval by the Ethics and Research Committee of the School of Public Health of Rio Grande do Sul, under the protocol CPS-ESP 496/09.

\section{RESULTS}

In the construction of the corpus of the inducing term violence against rural women through free association of words, we obtained 53 different words and expressions, divided into 213 expressed emergences by the set of participants. Among the words, a word was mentioned 23 times, whereas 11 words were cited only once.

Associating the frequency of emergence of the terms and their average positions of emergence, we generated Chart 1, as centrality. In the upper left quadrant (Quadrant 1), are the elements with lower order of emergence (more readily emerged) with higher frequencies, attributes that indicate the probable central core. In the universe of participants, it became evident, as central elements, the words fear, alcohol, overload of women' work, disrespect, physical aggression and aggression. 
In the lower right quadrant (Quadrant 4), the words of lower frequency and greater LRE (less readily emerged) are located, which form the peripheral system, presenting the words cowardice, deprivation, power and unstructured-family. It is reiterated that the peripheral system maintains a dialectic relationship with the central system, wherein any change in the central core depends on the relationship between central and peripheral systems, because this absorbs the information and filters them ${ }^{(7)}$. It can be said that peripheral system questions the central core and the potential inductor of changes to this core.

Chart 1 - Centralization of the terms emerged by all the participants of the study in response to stimuli - words that come to mind when they heard the statement violence against rural women.

\begin{tabular}{|c|c|c|c|c|c|c|}
\hline & \multicolumn{3}{|c|}{ LRE $<2.4$} & \multicolumn{3}{|c|}{ LRE $\geq 2.4$} \\
\hline & \multicolumn{3}{|c|}{ Quadrant 1} & \multicolumn{3}{|c|}{ Quadrant 2} \\
\hline & Word & $\mathbf{F}$ & LRE & Word & $\mathbf{F}$ & LRE \\
\hline \multirow{9}{*}{$f \geq 8$} & Aggression & 9 & 2.000 & Verbal-aggression & 10 & 2.600 \\
\hline & Physical-aggression & 9 & 1.444 & Culture & 16 & 3.250 \\
\hline & Alcohol & 14 & 1.929 & Submission & 14 & 3.000 \\
\hline & Disrespect & 10 & 2.100 & & & \\
\hline & Fear & 16 & 2.250 & & & \\
\hline & Overload of women work & 11 & 1.350 & & & \\
\hline & \multicolumn{3}{|c|}{$\begin{array}{l}\text { LRE }<2.4 \\
\end{array}$} & \multicolumn{3}{|c|}{ LRE $\geq 2.4$} \\
\hline & \multicolumn{3}{|c|}{ Quadrant 3 } & \multicolumn{3}{|c|}{ Quadrant 4} \\
\hline & Word & $\mathbf{F}$ & LRE & Word & $\mathbf{F}$ & LRE \\
\hline \multirow{8}{*}{$\mathrm{f} \leq \mathbf{3}<\mathbf{7}$} & Sexual-abuse & 7 & 2.286 & Cowardice & 7 & 2.714 \\
\hline & Disaffection & 4 & 1.750 & Family- unstructured & 5 & 2.800 \\
\hline & Insecure & 3 & 2.333 & Hard-access & 4 & 2.750 \\
\hline & Sexism & 5 & 2.200 & Lack-leisure & 3 & 3.333 \\
\hline & Financial-situation & 3 & 2.333 & Ignorance & 3 & 3.000 \\
\hline & & & & Power & 6 & 3.167 \\
\hline & & & & Deprivation & 6 & 2.500 \\
\hline & & & & Veiled & 5 & 3.400 \\
\hline
\end{tabular}

Source: Costa MC. General emergences of the study participants, cities from the southern half, RS, 2011.

Among the elements of the right upper quadrant (Quadrant 2), it is highlighted two terms to strengthen the central core - culture and submission - that were emerged respectively 16 times and 14 times, but with a LRE larger than average. In the left lower quadrant (Quadrant 3), it is highlights the words sexual abuse, sexism and unafecction. Both the quadrants representing the intermediate system are named like this for their approaches the peripheral or central core elements ${ }^{(11)}$.

The Chart presented below allow the visualization of the comparison of word associations between groups of study participants from their professional categories. By the fact of groups be constituted of small number of participants, it was decided to exclude the frequency less than 2.

In this sense, the group of managers and responsible for the women's health, it was observed that among the most frequent words for managers emerged: unstructured family and aggression. Among those responsible for women's health, we evidenced the word submission. When analyzing the common words between them, we identified alcohol, culture and fear, as demonstrated in Chart 2.

The second group analyzed was professionals and health workers who work in rural areas, grouped initially, in professional nurses and professionals physicians. In the analysis, it was observed that, for professional nurses, sexism, verbal-aggression and hard-access were most frequent words and expressions, and sexual abuse, the most frequent word for physicians (Chart 3).

Chart 2 - More frequent and common words in the group of managers and responsible for women's health in response to the stimuli - words that come to mind when they heard the statement violence against rural women.

\begin{tabular}{|c|c|c|c|c|c|}
\hline \multicolumn{3}{|c|}{ More frequent words } & \multicolumn{3}{|c|}{ Common words } \\
\hline Managers & & $\begin{array}{l}\text { Responsible } \\
\text { WH }\end{array}$ & & Man & $\begin{array}{l}\text { RES } \\
\text { WH }\end{array}$ \\
\hline $\begin{array}{l}\text { Unstruc- } \\
\text { tured-family }\end{array}$ & 2 & Submission & 2 Alcohol & 4 & 3 \\
\hline \multirow[t]{3}{*}{ Aggression } & 2 & & Culture & 4 & 3 \\
\hline & & & Fear & 3 & 3 \\
\hline & & & Disrespect & 2 & 1 \\
\hline
\end{tabular}

Source: Costa MC. Cities from the Southern half, RS; 2011.

In both professional categories, the words submission and culture were the most common, six and five times, respectively, for the group of nurses. However, each word was mentioned only once among physicians, which can configure an element of analysis influenced by gender, considering that the group of nurses is exclusively composed of women while physicians, in most cases, is composed by men. 
Chart 3 - More frequent and common words in the group of nurses and physicians in response to the stimuli - words that come to mind when they heard the statement violence against rural women

\begin{tabular}{|c|c|c|c|c|c|c|}
\hline \multicolumn{3}{|c|}{ More frequent word } & & \multicolumn{3}{|c|}{ Common word } \\
\hline Nurse & & Physician & & & Nur & Phys \\
\hline Sexism & 3 & Sexual-abuse & 5 & Submission & 6 & 1 \\
\hline Verbal-aggression & 2 & & & Culture & 5 & 1 \\
\hline Hard-access & 2 & & & Alcohol & 3 & 3 \\
\hline & & & & Disrespect & 3 & 3 \\
\hline & & & & Cowardice & 2 & 1 \\
\hline & & & & Aggression & 3 & 1 \\
\hline & & & & Fear & 3 & 1 \\
\hline & & & & Power & 3 & 1 \\
\hline & & & & $\begin{array}{l}\text { Overload } \\
\text { of women's } \\
\text { work }\end{array}$ & 1 & 4 \\
\hline & & & & $\begin{array}{l}\text { Unstructured- } \\
\text { family }\end{array}$ & 2 & 1 \\
\hline & & & & Privation & 1 & 2 \\
\hline
\end{tabular}

Source: Costa MC. Cities from the Southern half, RS; 2011.

The words alcohol and disrespect were common among the two groups, both at frequency 3 in each of them.

It was also performed the analysis of the most frequent and common words in the professional category nurse in relation to community health workers. Among nurses, the most frequent word was unstructured family while the words veiled, depreciation, lack dialogue and oppression were more frequent among community health workers, as shown in Chart 4.

Chart 4 - More frequent and common words in the group of nurses and community health agents in response to the stimuli words that come to mind when they heard the statement violence against rural women

\begin{tabular}{|c|c|c|c|c|c|}
\hline \multicolumn{3}{|c|}{ More frequent word } & \multicolumn{3}{|c|}{ Common words } \\
\hline Nurses & $\begin{array}{l}\text { Community health } \\
\text { agents }\end{array}$ & & & Enf & ACS \\
\hline \multirow[t]{14}{*}{$\begin{array}{l}\text { Unstructured- } \\
\text { Family }\end{array}$} & Veiled & 3 & Submission & 6 & 4 \\
\hline & Depreciation & 2 & Fear & 3 & 6 \\
\hline & Lack-of-dialogue & 2 & $\begin{array}{l}\text { Verbal- } \\
\text { aggression }\end{array}$ & 3 & 6 \\
\hline & Oppression & 2 & Culture & 1 & 5 \\
\hline & & & $\begin{array}{l}\text { Physical- } \\
\text { aggression }\end{array}$ & 1 & 4 \\
\hline & & & Aggression & 3 & 3 \\
\hline & & & $\begin{array}{l}\text { Overload } \\
\text { of women's } \\
\text { work }\end{array}$ & 1 & 4 \\
\hline & & & Sexism & 3 & 1 \\
\hline & & & Disrespect & 3 & 1 \\
\hline & & & Alcohol & 1 & 3 \\
\hline & & & Power & 3 & 1 \\
\hline & & & Privation & 1 & 3 \\
\hline & & & Hard-access & 2 & 1 \\
\hline & & & Cowardice & 2 & 1 \\
\hline
\end{tabular}

Source: Costa MC. Cities from the Southern half, RS; 2011.
When analyzing the emergences of Community Health Agents ( $\mathrm{CHA})$, in the relationship with physicians, it was identified that the words verbal aggression, unaffection, depreciation, lack-of-dialog, sexism and oppression were more frequent among community health agents, and among physicians, unstructured family was the most frequent, as shown in Chart 5.

Chart 5 - More frequent and common words in the group of community health agents and physicians in response to the stimuli words that come to mind when they heard the statement violence against rural women

\begin{tabular}{|c|c|c|c|c|c|}
\hline \multicolumn{3}{|c|}{ More frequent word } & \multicolumn{3}{|c|}{ Common word } \\
\hline \multicolumn{2}{|c|}{ Community health agent } & \multicolumn{2}{|l|}{ Physician } & \multirow{2}{*}{$\begin{array}{c}\mathrm{ACS} \\
\mathbf{1}\end{array}$} & \multirow{2}{*}{$\frac{\text { Méd }}{6}$} \\
\hline Verbal-aggression & 6 & $\begin{array}{l}\text { Unstructured- } 2 \\
\text { family }\end{array}$ & $\begin{array}{l}\text { Sexual- } \\
\text { abuse }\end{array}$ & & \\
\hline Disaffection & 2 & & $\begin{array}{l}\text { Overload } \\
\text { of women's } \\
\text { work }\end{array}$ & 4 & 4 \\
\hline Depreciation & 2 & & $\begin{array}{l}\text { Physical- } \\
\text { aggression }\end{array}$ & 4 & 1 \\
\hline Lack-of-dialogue & 2 & & Culture & 4 & 1 \\
\hline Sexism & 2 & & Submission & 4 & 1 \\
\hline \multirow[t]{3}{*}{ Oppression } & 2 & & Alcohol & 3 & 1 \\
\hline & & & Privation & 3 & 1 \\
\hline & & & Veiled & 3 & 1 \\
\hline
\end{tabular}

Source: Costa MC. Cities from the Southern half, RS; 2011.

Note the term sexual abuse, among the common words, mentioned six times by physicians and once by community health agents. It was identified with four emergences, the term overload of women's work. This refers to the overload of activities by rural women, whether at home or in the context of agriculture, farming, which, in a way, it is inferred by the study participants as a form of violence against these women.

\section{DISCUSSION}

The terms emerged by the study participants and demonstrated in Chart 1, identified that the words mentioned shows attributes that reflect male dominance and may indicate an awareness of conscience of gender domination. It is possible that we start to acknowledge difference as inequality of power and the exercise of male power begins to be questioned in their symbolic legitimacy.

This finding is instituting of male and female roles as elements of permanence of domination between genders, which ends justifying and naturalizing violence as constitutive of that relationship and socially acceptable ${ }^{(12)}$. However, admitting the transforming potential of these meanings, it may be said that the justifications that are based on these domination arguments, are possible to be overcome. In the health area, for example, the notion of integrality can feed new perspectives on gender domination and be instituting of new practices. 
Thus, assuming this influence, the emergence in both quadrants qualify women as submissive and justify the motives of the perpetrator for acts of violence, linking them to the words culture and sexism. This finding reinforces the symbolic domination suffered by rural women, especially in marital relations, either by focusing on the women's decision that incorporated submission behaviors or pressures to maintain the family, or in the image that people have on the ideal woman. As for the term culture, it is possible that this is emerged pejoratively, with particular reference to the Pomeranian culture, strongly present in this region. In this sense, it serves well to justify inaction in Institutional and professionals' actions, in their isolation of consultation practices. The difficulties in producing adequate attention, considering these lives in violence, induce legitimate justifications for the particular culture of social groups.

However, it is considered that health professionals cannot ignore the situations of violence, because their intervention is necessary for the prevention, detection and treatment of the problem. Thus, an increased awareness and training of professionals, especially in regard to the early identification of domestic violence, would imply a more appropriate and effective care for women ${ }^{(13)}$.

The possible central core (Quadrant 1 ) initially suggests the representation related to the word fear, which is the determination of aspects guided to gender, that is, the social and cultural position of inferiority of women, which justifies and naturalizes violence. Associated with this, the words alcohol and disrespect appear as associated emergences often considered triggers to acts of aggression, which helps to justify and give invisibility to these acts against rural women as a result of uncontrolled moments.

For the word fear, it appears that not only fear is linked to the figure of women in situations of violence, but also the attitude of many health professionals against this issue, in such a way that the fear and the feeling of helplessness of professionals and these women before the perpetrators reflect this male domination in society and, in particular, in some cultures, where violence is sustained in power inequalities imposed and naturalized in the male/ female relation.

As noted in Chart 2, the words alcohol and culture were frequently emerged in the managers and responsible for women's health. This fact is due to the context of this research, in which the frequent use of alcohol by men is justified in ethnic-cultural tradition, mainly related to the Pomeranian culture, naturalizing both consumption and violence against women as effect and tradition, therefore, natural in man-woman relationship.

In this approach, linking violence to a clinical diagnosis of alcoholism, the perpetrator assumes no responsibility for violent attitudes, recognized as natural among cultural tradition of these rural communities, fully justified by the diagnostic illegitimacy. Often, representatives of government health area understand that in this context, violence against women and alcohol use are natural and transiting between the public and private sphere, involving disease, moral and cultural values being modulated by differences based on gender constructions, thus not being responsible or liable to intervene by the public authorities from the health sphere.

In comparing the emergences of the group of nurses and physicians presented in Chart 3, there was an association between the words alcohol and disrespect, which justifies the attitudes of disrespect of men against women due to the use of alcohol. Emergences which qualify the man as an alcoholic, may also indicate that the disrespect to women occurs only when the man is under the influence of alcohol, unconfiguring gender violence, which incorporates the inequalities of power in male-female relationships and establishing legitimacy to violent acts occurring in this relationship.

On the comparison of the emergence of common words in the group of nurses and community health agents (CHA), we found the word submission with six emergences by nurses and four by the CHA. It can be inferred that submission persists introduced as an acceptable social model for women, which reinforces the guilt and naturalization of such violence.

The common word fear appears more in the category of community health agents. This can reveal the proximity of CHA with the women of their covered communities, allowing them to identify as the most expressive form of violence, verbal aggression and fear. Fear is often represented by the permanence of these women in situations of violence, for the apprehension of what may happen if they try to react to situations experienced. It also reflects the fear that the health professional feel when engaging with these situations, which helps the perpetuation of such violent events as part of the daily lives of these women, in which many of them have stories of resignation as gender destiny, and professionals can do nothing.

However, violence against women is considered a societal problem that requires collective action strategies, covering both legal and health needs simultaneously. Also, social support is important to help women in situations of violence, especially with regard to the suffering caused by such situations. Thus, health professionals can do much to enhance the therapeutic jurisprudence and reduce violence against women ${ }^{(14)}$.

Among the most common words, it was identified between both groups, the emergence of the word aggression. This shows that, for both groups, violence against rural women focuses on aggression, which demonstrates targeting the most plausible and perceptible forms of violence, or those who leave any visible marks and diagnosable, ie, capable of be attributed to an ICD (International Classification of Diseases).
Social representations of violence against rural women: unveiling senses in multiple views Costa MC, Lopes MJM, Soares JSF 
The frequency of the term sexual abuse, in the emergence of physicians, observed in Chart 5, reveals that, for this group, violence against rural women is linked to the acts which represents male domination on the female body and sexuality, showing the social reproduction of the sexual rights of man over his wife. It is inferred that the cultures of hegemonic male gender (heteronormative) may be influencing this kind of reference to sexual abuse, because in this group there is a greater number of men. It is noted that the analysis of gender, it is common to find this view of sexuality as instinctive biological urge and is much more historically applied to male sexuality that dominates, controls and is violent ${ }^{(15)}$, being accepted, often as a natural.

From the words mentioned in the groups of physicians and community health agents, one can evidence that the participants consider that for some rural women, violence is a destination, which comes from the consent/resignation, guilt/fear. Thus, violence is also addressed in the institutional context of health and end up being naturalized and trivialized by the sociocultural tradition marked by hierarchical gender relations.

As seen in Chart 5, in both groups, the term overload of women's work was frequent emerged. It is inferred that rural women have double or triple shifts of work, determined by the subsistence of male and female social roles. In the understanding of the participants, this fact sets violence by work overload, being linked to gender inequalities, because domestic services and care for the house and the children are considered specific and unique for women. Rural women occupy a subordinate position and their work often appears as help, even when they work as much as men or develop activities just like them. This is an indication that women's work is seen as an extension of domestic work, reinforcing the invisibility surrounding the perception of women's role in the family agriculture ${ }^{(16)}$.

Emergences also show particular elements, which are from the context of rural areas, where the place of production (farming, crops) is a masculine symbolic domain; the female dominance is set in the private space, that is, the reproductive and somewhat unproductive sphere in relation mainly to production/generation of the income system. These domains, in agricultural practice of women, make them transit and have responsibilities in both spheres, resulting in work overload and inequalities between men/women in the spaces of production and reproduction.

In analyzes of emergences between professional categories, it is observed that the physicians and nurses emergences, in relation to community health agents, often bringing the term unstructured-family. Then several questions arise: does this reference is a clue that there was adequate previous structure that was good? When women were unaware of their rights and were bitten in silence, does it mean that the family was structured? Or, when women were confined to their role in the family and in social and family hierarchy was it different? Or, do professionals represent the (un)structure family to take on the responsibility of intervention, since it's a private or social problem?

It was also observed, in the representation of $\mathrm{CHA}$, a more sensitive tensioning to suffering himself/herself than among other professionals and managers, fleeing from biological or simply own representations of woman's destiny. This can be linked to the ability of $\mathrm{CHA}$ to view this problem in everyday households and local social context, not only in its biological centrality, which shows greater accountability by the contextual and relational demands of rural communities.

Developing effective practices for the identification of women experiencing domestic violence, as well as the prevention of victimization requires a broad understanding of the effects of domestic violence and the challenges for health professionals in dealing with it. Thus, new perspectives are necessary to the creation of appropriate practices and a responsible approach to domestic violence. A broader social and political commitment to addressing violence against women is necessary, as well as recognition of violence and their suffering resulting from a capable and legitimate state intervention in health services ${ }^{(17)}$.

\section{CONCLUSION}

In the apprehension of representations of violence against rural women, it was observed that in the view of managers and professionals, the lives of rural women is tensioned by multiple aspects of what it means to be a woman. Thus, conflicts and challenges constitute the practical life of these women who, throughout the advances between new and conservative, the central and peripheral, attest the permanence of male domination.

Social Representations, as interpretative forms of social reality in that environment, associate violence to the asymmetries of power, where power inequalities justify the nature of female subjection. This legitimizes gender attitudes that crystallize male and female roles as elements of domination between the gender, being violence the result of this relationship, which is socially acceptable.

The analysis, particularly in the field of permanence of the justifications for violence against women, show the need to produce ruptures in established and entrenched forms of health care, in the conservative and stereotypical views of violence understanding, allowing an extended reading of the elements inserted in these complex events. We argue, in particular, that there is a need to do readings of health care offered in professional practices, permeating them in reflections of gender in an attempt not to produce inequities in rural scenario. In addition, health 
actions, women in situations of violence, in fact, seem to require an intervention that includes new elements of understanding of the subject-women (re)building or (re) signifying what are health needs, care and assistance. From this, new perspectives and coping strategies may be present in professional practices.

\section{REFERENCES}

1. Schraiber LB, D'Oliveira AFPL, Couto MTF. Violência e saúde: contribuições teóricas, metodológicas e éticas de estudos da violência contra a mulher. Cad Saúde Pública. 2009; 25 Supl. 2:S205-16.

2. Santi LN, Nakano AMS, Lettiere A. Percepção de mulheres em situação de violência sobre o suporte e apoio recebido em seu contexto social. Texto Contexto Enferm. 2010; 19(3):417-24.

3. Guedes RN, Fonseca RMGS, Egry EY. The evaluative limits and possibilities in the Family Health Strategy for gender-based violence. Rev Esc Enferm USP [Internet]. 2013 [cited 2013 July 28];47(2):304-11. Available from: http://www.scielo.br/pdf/ reeusp/v47n2/en_05.pdf

4. Lettiere A, Nakano AMS, Rodrigues DT. Violence against women: visibility of the problem according to the health team. Rev Esc Enferm USP [Internet]. 2008 [cited 2013 July 28];42(3):467-73. Available from: http://www.scielo.br/pdf/ reeusp/v42n3/en_v42n3a07.pdf

5. Moscovici S. Representações sociais: investigação em psicologia social. Petrópolis: Vozes; 2003.

6. Porto MSG. Re-pensando crenças e valores: sociologia e representações sociais. In: Almeida AMO, Jodelet $D$, organizadores. Representações sociais: interdisciplinaridade e diversidade de paradigmas. Brasília: Thesaurus; 2009. p. 139-62.

7. Spink MJP. O estudo empírico das representações sócias. In: Spink MJP, organizadora. O conhecimento no cotidiano: as representações sociais na perspectiva da psicologia social. São Paulo: Brasiliense; 2004. p. 85-145.

8. Abric JC. Pratiques sociales et représentations. Paris: Presses Universitaires de France; 1994.

9. Vèrges P. Conjunto de programas que permitem a análise de evocações: EVOC: manual. Versão 5. Aix-em-Provence: [S. n.]; 2002.

10. Sá CP. Núcleo central das representações sociais. Petrópolis: Vozes; 1996.

11. Gomes AMT, Oliveira DC. Estudo da estrutura da representação social da autonomia profissional em enfermagem. Rev Esc Enferm USP. 2005;39(2):145-53.

12. Costa MC, Lopes MJM. Elements of comprehensiveness in the professional health practices provided to rural women victims of violence. Rev Esc Enferm USP [Internet]. 2012 [cited 2013 July 28];46(5):1088-95. Available from: http:// www.scielo.br/pdf/reeusp/v46n5/en_08.pdf

13. Gracia E, Lilia M. Los profesionales de la salud y la prevención de la violencia doméstica contra la mujer. Rev Med Chile. 2008;136(3):394-400.

14. Wright CV, Johnson DM. Correlates for legal help-seeking: contextual factors for battered women in shelter. Violence Vict. 2009;24(6):771-85.

15. Giffin K. Violência de gênero, sexualidade. Cad Saúde Pública. 1994;10 Supl.1:S146-55.

16. Lopes MJM. Divisão do trabalho e relações sociais de sexo: pensando a realidade das trabalhadoras do cuidado de saúde. In: Lopes MJM, Meyer DE, Waldow VR, organizadoras. Gênero e saúde. Porto Alegre: Artes Médicas; 1996. p. 55-62.

17. Husso $M$, Virkki $T$, Notko $M$, Holma J, Laitila $A$, Mäntysaari $\mathrm{M}$. Making sense of domestic violence intervention in professional health care. Health Soc Care Community. 2012;20(4):347-5. 


\section{ERRATUM}

As published in Volume 48, number 2 of 2014,on pages 221 to 222, the published references of the article "Representações sociais da violência contra mulheres rurais: desvelando sentidos em múltiplos olhares" should be excluded; therefore, the following list should be considered:

1. Schraiber LB, D’Oliveira AFPL, Couto MTF. Violência e saúde: contribuições teóricas, metodológicas e éticas de estudos da violência contra a mulher. Cad Saúde Pública. 2009; 25 Supl. 2:S205-16.

2. Santi LN, Nakano AMS, Lettiere A. Percepção de mulheres em situação de violência sobre o suporte e apoio recebido em seu contexto social. Texto Contexto Enferm. 2010; 19(3):417-24.

3. Guedes RN, Fonseca RMGS, Egry EY. The evaluative limits and possibilities in the Family Health Strategy for gender-based violence. Rev Esc Enferm USP [Internet]. 2013 [cited 2013 July 28];47(2):304-11. Available from: http://www.scielo.br/pdf/reeusp/v47n2/ en_05.pdf

4. Lettiere A, Nakano AMS, Rodrigues DT. Violence against women: visibility of the problem according to the health team. Rev Esc Enferm USP [Internet]. 2008 [cited 2013 July 28];42(3):467-73. Available from: http://www.scielo.br/pdf/reeusp/v42n3/ en_v42n3a07.pdf

5. Moscovici S. Representações sociais: investigação em psicologia social. Petrópolis: Vozes; 2003.

6. Porto MSG. Re-pensando crenças e valores: sociologia e representações sociais. In: Almeida AMO, Jodelet D, organizadores. Representações sociais: interdisciplinaridade e diversidade de paradigmas. Brasília: Thesaurus; 2009. p. 139-62.

7. Spink MJP. O estudo empírico das representações sócias. In: Spink MJP, organizadora. O conhecimento no cotidiano: as representações sociais na perspectiva da psicologia social. São Paulo: Brasiliense; 2004. p. 85-145.

8. Abric JC. Pratiques sociales et représentations. Paris: Presses Universitaires de France; 1994.

9. Vèrges P. Conjunto de programas que permitem a análise de evocações: EVOC: manual. Versão 5. Aix-em-Provence: [S. n.]; 2002.

10. Sá CP. Núcleo central das representações sociais. Petrópolis: Vozes; 1996.

11. Gomes AMT, Oliveira DC. Estudo da estrutura da representação social da autonomia profissional em enfermagem. Rev Esc Enferm USP. 2005;39(2):145-53.

12. Costa MC, Lopes MJM. Elements of comprehensiveness in the professional health practices provided to rural women victims of violence. Rev Esc Enferm USP [Internet]. 2012 [cited 2013 July 28];46(5):1088-95. Available from: http://www.scielo.br/pdf/ reeusp/v46n5/en_08.pdf

13. Gracia E, Lilia M. Los profesionales de la salud y la prevención de la violencia doméstica contra la mujer. Rev Med Chile. 2008;136(3):394-400.

14. Wright CV, Johnson DM. Correlates for legal help-seeking: contextual factors for battered women in shelter. Violence Vict. 2009;24(6):771-85.

15. Giffin K. Violência de gênero, sexualidade. Cad Saúde Pública. 1994;10 Supl.1:S146-55.

16. Lopes MJM. Divisão do trabalho e relações sociais de sexo: pensando a realidade das trabalhadoras do cuidado de saúde. In: Lopes MJM, Meyer DE, Waldow VR, organizadoras. Gênero e saúde. Porto Alegre: Artes Médicas; 1996. p. 55-62.

17. Husso M, Virkki T, Notko M, Holma J, Laitila A, Mäntysaari M. Making sense of domestic violence intervention in professional health care. Health Soc Care Community. 2012;20(4):347-55. 